\title{
Isolation and characterization of Vibrio alginolyticus from cultured amphioxus Branchiostoma belcheri tsingtauense
}

\author{
Yuxia Zou ${ }^{1,2}$, Cuiping $\mathrm{MA}^{3}$, Yanfei ZHANG ${ }^{1,2}$, Zongjun Du ${ }^{4}$, Feng You ${ }^{1,2}$, Xungang TAN ${ }^{1,2 *}$ \\ \& Pei-Jun ZHANG ${ }^{1,2}$ \\ ${ }^{1}$ Key Laboratory of Experimental Marine Biology, Institute of Oceanology, Chinese Academy of Sciences, Qingdao, Shan- \\ dong 266071, People's Republic of China; e-mail: tanx@qdio.ac.cn \\ ${ }^{2}$ Laboratory for Marine Biology and Biotechnology, Qingdao National Laboratory for Marine Science and Technology, \\ Qingdao, People's Republic of China \\ ${ }^{3}$ College of Chemistry and Molecular Engineering, Qingdao University of Science and Technology, Qingdao, Shandong \\ 266042, People's Republic of China \\ ${ }^{4}$ Marine College, Shandong University Weihai, Weihai, People's Republic of China
}

\begin{abstract}
Amphioxus is an intermediary species bridging invertebrates and vertebrates used to study the development and evolution of species and genes. In this study, the dominant bacterial strain was isolated from tail lesions of cultured amphioxus and designated WW1. Challenge by intramuscular microinjection revealed the $50 \%$ lethal dose of WW1 to be $9 \times 10^{2}$ bacteria/g amphioxus body weight. Based on $16 \mathrm{~S}$ rRNA gene sequence, physiological and biochemical characteristics, and species-specific collagenase gene marker, WW1 was identified as Vibrio alginolyticus. To our knowledge, this is the first report on the isolation of $V$. alginolyticus as pathogen from amphioxus. This study extends the known host range of $V$. alginolyticus and may provide information helpful in preventing and managing its occurrence in cultured animals.
\end{abstract}

Key words: amphioxus; 16S rRNA gene; collagenase; pathogen isolation; experimental challenge; Vibrio alginolyticus.

Abbreviations: NS, normal saline; TCBS, thiosulphate citrate bile salts sucrose.

\section{Introduction}

The cephalochordate amphioxus (lancelet), an intermediate species between vertebrates and invertebrates known as Branchiostoma, has long been regarded as an important animal model for research into evolution and development (Gans 1996). Amphioxus is used in studies of the origin of vertebrates from invertebrates (Holland et al. 2015), as it not only shares a highly similar adult body plan and embryonic development process regulated by a homologous gene network with vertebrates, but also a high degree of synteny in the genome (Holland 2014).

To obtain embryos, mature amphioxi are traditionally captured in the breeding season and maintained in a laboratory, hence studies use of live embryos is timelimited. The natural amphioxus population has significantly decreased due to environmental pollution (Fang 1987), and, since the end of the past century, amphioxus has been artificially cultured (Wu et al. 1994; Holland \& Yu 2004; Yasui et al. 2007). Over our four years of culture, lesions of the tail and exposed notochords were found in some amphioxi. Most infected amphioxi lay on the surface of the sand and were unable to burrow into the sand. Infection spread to other animals with high mortality. Mortality due to disease has become a major problem. The isolation and characterization of pathogens from cultured amphioxus might be helpful to prevent and treat disease.

Here, we isolated and identified a pathogenic strain of Vibrio alginolyticus from cultured amphioxus via the 16S rRNA gene sequence, species-specific gene marker, physiological and biochemical characteristics.

\section{Material and methods}

Amphioxus culture

Amphioxi (Branchiostoma belcheri tsingtauense) were captured from Shazikou, Qingdao, and maintained for 4 years at the Institute of Oceanology, Chinese Academy of Sciences, Qingdao, People's Republic of China. Fish were held in tanks with a $10 \mathrm{~cm}$ layer of sand and fed daily with frozen/fresh unicellular algae (Isochrysisgalbana and/or Chlorella vulgaris). The sea water was changed daily.

Isolation of pathogen

Sterile inoculating needles were used to scrape the damaged tails of five diseased amphioxi with the same symptoms and to streak the plates of ZoBell 2216E. Plates were incubated

\footnotetext{
* Corresponding author
} 
at $20-25^{\circ} \mathrm{C}$ for up to 2 days. A bacterial strain, designated WW1, from the dominant colonies was purified and stored at $-80{ }^{\circ} \mathrm{C}$ with $15 \%$ glycerol for long-term storage.

\section{$16 S$ rRNA gene amplification and sequencing}

Genomic DNA of WW1 was extracted and purified by conventional SDS-protease (Ausubel et al. 1995). The 16S rRNA gene was amplified as described by Lane (1991) using $27 \mathrm{f}$ and 1492r oligonucleotides as primers. The PCR product was cloned into pEASY-T1 (TransGen Biotech, China) and sequenced (Boshang, Shanghai, China).

\section{S rRNA gene phylogenetic analyses}

A BLAST (Altschul et al. 1997) search was conducted of the database of strains with validly published prokaryotic names (Chun et al. 2007) to search homologous sequences of the $16 \mathrm{~S}$ rRNA gene. The 28 sequences with the highest scores were selected for the calculation of pair-wise sequence similarity using a global alignment algorithm, implemented in the EzTaxon server (http://www.eztaxon.org/; Chun et al. 2007). Sequence alignment was performed by Clustal Omega via the EBI's server (http://www.ebi.ac.uk/Tools/msa/ clustalo/). The evolutionary history was inferred using the maximum likelihood method based on the Jukes-Cantor model (Jukes \& Cantor 1969). Initial tree(s) for the heuristic search were obtained automatically by applying neighbourjoining and BioNJ algorithms (Saitou \& Nei 1987) to a matrix of pair-wise distances estimated using maximum composite likelihood and selecting the topology with superior log-likelihood value. The tree was drawn to scale, with branch lengths measured in the number of substitutions per site. The analysis involved 29 nucleotide sequences. All positions with less than $95 \%$ site coverage were eliminated, i.e. fewer than $5 \%$ alignment gaps, missing data, and ambiguous bases were allowed at any position. The final dataset comprised 1,276 positions. Evolutionary analyses were conducted in the MEGA6 software (Tamura et al. 2013).

Physiological and biochemical characteristics of WW1 For analysis of physiological and biochemical characteristics, WW1 was cultured for $24-48 \mathrm{~h}$ on ZoBell $2216 \mathrm{E}$ or thiosulphate citrate bile salts sucrose (TCBS) agar. Reagents for WW1 growth medium and analysis of physiological and biochemical characteristics except API 20E system were purchased from the Hangzhou Microbial Reagent Corporation (Hangzhou, China). To identify the species of WW1, the API 20E system (bioMérieux) was conducted according to the manufacturer's instructions, with the exception of the incubation being prepared by suspending cells in a $2 \%(\mathrm{w} / \mathrm{v})$ $\mathrm{NaCl}$ solution. API $20 \mathrm{E}$ is a standardized identification system using 21 individual biochemical tests. The API $20 \mathrm{E}$ strips were read after 2 days of incubation at $28^{\circ} \mathrm{C}$. The results of API $20 \mathrm{E}$ analysis and physiological characteristics of WW1 are listed in Table 1.

\section{Detection of species-specific collagenase gene}

A PCR assay using a collagenase-specific primer for detection of Vibrio alginolyticus was preformed as previously described (Di Pinto et al. 2005). The forward primer was 5'-CGAGTACAGTCACTTGAAAGCC-3' and the reverse was 5'-CACAACA GAACTCGCGTTACC-3'. The PCR solution $(25 \mu \mathrm{L})$ contained $12.5 \mu \mathrm{L} 2 \times \operatorname{Taq}\left(2 \mathrm{mM} \mathrm{MgCl}_{2}\right.$, $0.2 \mathrm{mM}$ dNTPs, and 0.3 unit Taq polymerase), $0.5 \mu \mathrm{M}$ each of the primers, and $0.5 \mu \mathrm{L}$ DNA. The PCR protocol was $1 \mathrm{~min} 30 \mathrm{~s}$ at $94^{\circ} \mathrm{C} ; 35$ cycles of $30 \mathrm{~s}$ at $94^{\circ} \mathrm{C}, 30 \mathrm{~s}$ at $57^{\circ} \mathrm{C}$, and $60 \mathrm{~s}$ at $72^{\circ} \mathrm{C}$; and $5 \mathrm{~min}$ at $72^{\circ} \mathrm{C}$. The PCR product was purified and sequenced (Boshang, Shanghai, China).
Table 1. Physiological and biochemical properties of strain WW1.

\begin{tabular}{lcc}
\hline Test & WW1 & V. alginolyticus \\
\hline O-Nitrophenyl-D-galactopyranoside & - & - \\
Arginine dihydrolase & - & - \\
Lysine decarboxylase & + & + \\
Ornithine decarboxylase & - & + \\
Citrate utilization & + & + \\
$\mathrm{H}_{2}$ S production & - & - \\
Urease & - & - \\
Indole production & + & + \\
Voges-Proskauer reaction & + & Undetected \\
Gelatinase & - & + \\
Glucose fermentation & + & + \\
Mannitol fermentation & + & + \\
Inositol fermentation & - & - \\
Sorbitol fermentation & - & - \\
Rhamnose fermentation & - & - \\
Sucrose fermentation & + & + \\
Melibiose fermentation & - & - \\
Amygdalin fermentation & + & - \\
Arabinose fermentation & - & - \\
Oxidase & + & + \\
\hline
\end{tabular}

Growth in $1 \%$ tryptone plus $\mathrm{NaCl}$

$0 \% \mathrm{NaCl}$

$3,6,8$ and $10 \% \mathrm{NaCl}$

$+\quad+$

Growth in alkaline peptone water at different temperatures

\begin{tabular}{lll}
\hline $4^{\circ} \mathrm{C}$ & - & - \\
30,35 and $40^{\circ} \mathrm{C}$ & + & + \\
\hline
\end{tabular}

${ }^{a}$ The strain $V$. alginolyticus ATCC 33787 (González-Escalona et al. 2006).

\section{Determination of $L D_{50}$ of $W W 1$}

WW1 was cultured in ZoBell 2216E broth. Cells in the exponential phase were obtained by centrifugation and washed with sterilized $0.9 \%$ normal saline twice. The cell pellet was re-suspended in sterilized NS to obtain a homogeneous suspension. Four 10-fold dilutions of bacteria $\left(1.2 \times 10^{1}-\right.$ $1.2 \times 10^{4}$ bacteria per $\left.0.5 \mu \mathrm{L}\right)$ were used to infect $8 \mathrm{am}$ phioxi at each dilution and plated in triplicate on TCBS plates for counting viable bacteria.

Forty healthy amphioxi (body weight of amphioxus was about $0.25 \mathrm{~g}$ ) were randomly allocated to five groups of eight in $400 \mathrm{~mL}$ fibre glass tanks supplied with seawater $(37.5 \%$ salinity). The photoperiod followed the natural cycle $(10 \mathrm{~h}$ light / $14 \mathrm{~h}$ dark), and water temperature was maintained at $24 \pm 0.5^{\circ} \mathrm{C}$. To decrease background interference and obtain the most valid data possible, the amphioxi were unfed 1 day prior to infection. Each amphioxus was injected intramuscularly (Pli-100 Picroinjector, Harvard apparatus) with $0.5 \mu \mathrm{L}$ of dilution containing $1.2 \times 10^{1}-1.2 \times 10^{4}$ bacteria in sterilized NS with $0.1 \%$ phenol red to confirm injection. Controls were microinjected with $0.5 \mu \mathrm{L}$ sterilized NS with $0.1 \%$ phenol red. Mortality was recorded for 8 days. The species of the dominant bacterial strain isolated from dead animals was confirmed using collagenase-specific primer by PCR as described above.

$\mathrm{LD}_{50}$, the median lethal dose, is a measure of the lethal dose of pathogen and its value for a pathogen is the dose required to kill half the members of a tested population after specified test duration. The $\mathrm{LD}_{50}$ value was calculated by 


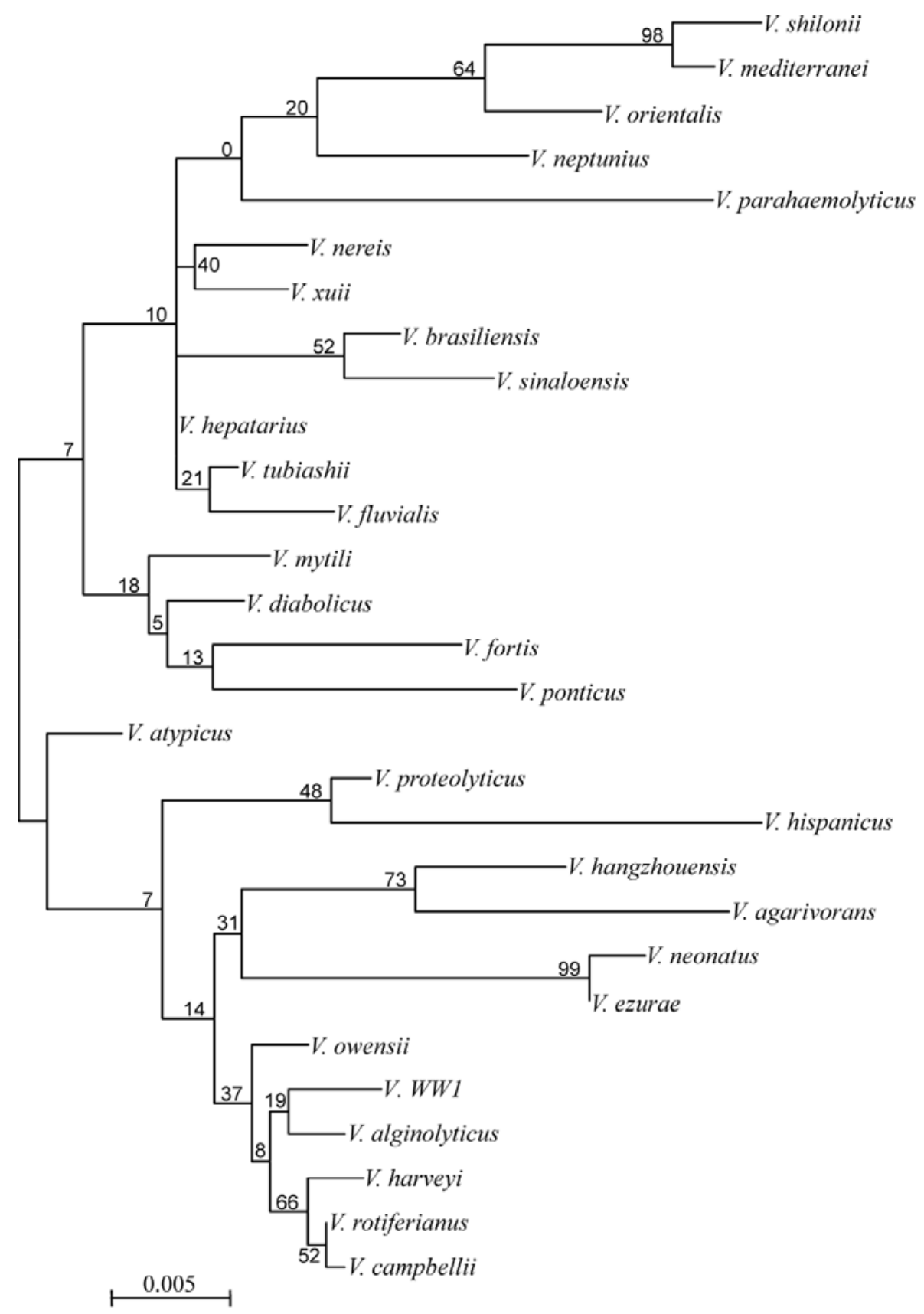

Fig. 1. Phylogenic tree of Vibrio alginolyticus WW1 based on a fragment of the 16S rRNA gene. The tree with the highest loglikelihood (-3886.8619) is shown. The tree is drawn to scale, with branch lengths measured in the number of substitutions per site. The number at the node is the bootstrap value (Felsenstein 1985). The bacteria and their 16S rRNA gene used were Vibrio alginolyticus WW1 (GenBank accession No.: KX425011); V. owensii DY05T (GU018180); V. rotiferianus LMG 21460T (AJ316187); V. campbellii ATCC 25920T (X74692); V. diabolicus HE800T (X99762); V. harveyi ATCC 14126T (X74706); V. alginolyticus ATCC 17749T (X56576); V. proteolyticus ATCC 15338T (X74723); V. atypicus HHS02T (FJ009624); V. mytili CECT 632T (X99761); V. tubiashii ATCC 19109T (X74725); V. fortis LMG 21557T (AJ514916); V. nereis ATCC 25917T (X74716); V. hangzhouensis CN83T (EU082035); V. hepatarius LMG 20362T (AJ345063); V. neonatus HDD3-1T (AY426979); V. parahaemolyticus ATCC 17802T (X56580); V. ezurae HDS1-1T (AY426980); V. brasiliensis LMG 20546T (AJ316172); V. xuii LMG 21346T (AJ316181); V. neptunius LMG 20536T (AJ316171); V. sinaloensis CAIM 797T (DQ451211); V. agarivorans CECT 5085T (AJ310647); V. orientalis ATCC 33934T (X74719); V. hispanicus LMG 13240T (AY254039); V. shilonii AK1T (AF007115); V. fluvialis NCTC 11327T (X76335); V. mediterranei CIP 103203T (X74710); V. ponticus CECT 5869T (AJ630103).

the method of Reed \& Muench (1938). Briefly, the dilutions that kill fewer and more than $50 \%$ of the tested animals are determined, and the concentration killing $50 \%$ was calculated as proportional distance (PD) according the formula:

$\mathrm{PD}=[50 \%-($ mortality at dilution next below $)] /$ [(mortality next above $)-($ mortality next below $)]$

\section{Results}

Identification of the dominant bacterial strain isolated from infected amphioxus

The dominant bacterial strain was Gram-negative and produced swarming colonies on ZoBell 2216E agar and was designated WW1. WW1 grew in the presence of 


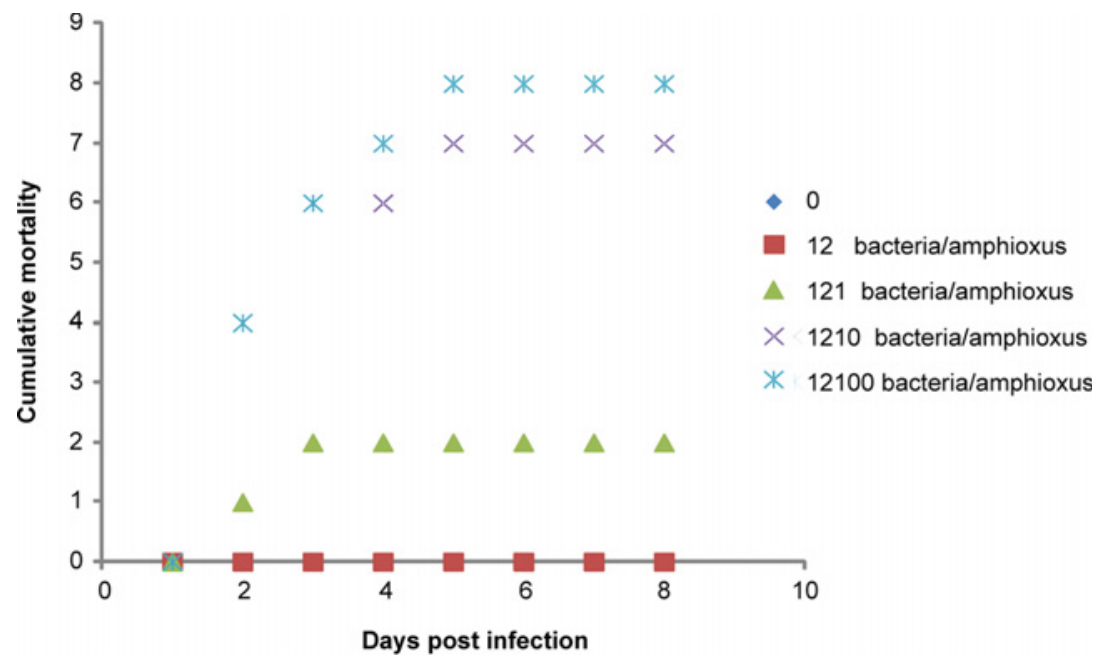

Fig. 2. Amphioxus cumulative mortality after bacterial infection at $24 \pm 0.5^{\circ} \mathrm{C}$.

$10 \% \mathrm{NaCl}$ and showed a bright yellow circular appearance on TCBS agar. A fragment of $16 \mathrm{~S}$ rRNA gene of WW1 was isolated by PCR and sequenced. The result showed that the WW1 $16 \mathrm{~S}$ rRNA gene exhibits the highest identity $(99 \%)$ to those of the Vibrio genus. Phylogenetic analysis of the $16 \mathrm{~S}$ rRNA gene suggested that the WW1 was closest to Vibrio alginolyticus (Fig. 1). The result of API 20E tests showed that WW1 was closest to $V$. alginolyticus with the identity of $86.2 \%$.

The collagenase gene has been used as a specific marker to identify $V$. alginolyticus (Di Pinto et al. 2005; Cai et al. 2006). Collagenase gene-specific primers were used to amplify a partial fragment (700-800 bp; GenBank accession No.: KX425012). Sequencing and BLASTX search revealed the encoded amino-acid sequence to be $100 \%$ identical to the collagenase of three $V$. alginolyticus strains.

Based on the results above, WW1 was identified as $V$. alginolyticus and designated $V$. alginolyticus WW1.

\section{Symptoms of infected amphioxi}

After microinjection of healthy amphioxi with WW1, the injection site (about $1 \mathrm{~cm}$ from the tail) became necrotic and the notochord was exposed. The control group showed no symptoms. The symptoms of infected amphioxi, including ulcers, were similar to those of fish and crustaceans infected by $V$. alginolyticus (Thompson et al. 2006) and to those of the naturally infected cultured amphioxi, suggesting $V$. alginolyticus WW1 as the responsible pathogen.

\section{The virulence of $V$. alginolyticus $W W 1$}

After injection of V.alginolyticus WW1, mortality was recorded for 8 days (Fig. 2). The $\mathrm{LD}_{50}$ was found to be $9 \times 10^{2}$ bacteria/g amphioxus body weight. After 8 days, no abnormality or mortality was seen in control animals.

\section{Discussion}

In present study, a bacterial pathogen of amphioxus was isolated and characterized. To identify the strain, we first performed 16S rRNA gene phyolgenetic analyses and knew that we are working with the Vibrio genus. The result of API $20 \mathrm{E}$ shows that WW1 was most close to $V$. alginolyticus with the identity of $86.2 \%$. Three factors (ornithine decarboxylase, gelatinase, amygdalin fermentation) differed between our strain and the type strain. However, according to Brenner et al. (2004a), $47 \%$ and $26 \% V$. alginolyticus strains differ from the type strains for ornithine decarboxylase and gelatinase, respectively. Hence only the difference in amygdalin fermentation may be meaningful. In addition, the colony characteristics of growth salinity and temperature described by Brenner et al. (2004b) identify our strain as close to the type strain. The collagenase gene confirmed WW1 as $V$. alginolyticus. Its virulence in the amphioxus was confirmed by artificial infection.

This is the first report of $V$. alginolyticus as a pathogen of amphioxus. $V$. alginolyticus occurs in coastal waters and sediments worldwide (Wong et al. 1992) and has been isolated from species including sea horse Hippocampus reidi (Balcázar et al. 2010; Martins et al. 2010), gilthead sea bream Sparus aurata (Balebona et al, 1998), silver seabream Sparus sarba (Li 2002), sea bass Dicentrarchus labrax (Ben KahlaNakbi et al. 2009), mussels Mytilus edulis (AnguianoBeltrán et al. 2004; Lhafi \& Kühne 2007), prawns Penaeus monodon and Penaeu sjaponicus (Lee et al. 1996a,b; Selvin \& Lipton 2003), abalone Haliotis diversicolor (Liu et al. 2001) and humans (Colwell \& Grimes 1984). Symptoms of $V$. alginolyticus infection include septicemia, exophthalmia, corneal opaqueness, ascites, lethargy, melanosis ulcers, and red spots or reddish colour of the entire body (Thompson et al. 2006). In humans, $V$. alginolyticus can cause otitis and wound infection (Reilly et al. 2011), and occasionally life-threatening infections in immunocompromised individuals (Lee et al., 2008). It can result in high mortality of cultured fish (Balebona et al. 1998; Zorilla et al. 2003; Ben Kahla-Nakbi et al. 2006). The discovery of $V$. alginolyticus as a pathogen of amphioxus extends its known host range. 
The amphioxus has been used as a model for study of development and evolution of species, genes, and gene regulatory networks. An adaptive immune system has been confirmed in amphioxus, providing an opportunity to study the origin and evolution of its key molecules (Cannon et al. 2002; Sato et al. 2003; Yu et al. 2005). When zebrafish Danio rerio was challenged with $V$. alginolyticus AB 209306 (CCTCC) by intramuscular injection, the $\mathrm{LD}_{50}$ was $9.69 \times 10^{4}$ bacteria/g body weight (Liu et al. 2011). Grouper Epinephelus awoara was injected intramuscularly with $V$. alginolyticus HY9901 with the resulting $\mathrm{LD}_{50}$ of $2 \times 10^{4}$ bacteria/g body weight (Zhou et al. 2013). The $\mathrm{LD}_{50}$ of $V$. alginolyticus WW1 isolated in this study was $9 \times 10^{2}$ bacteria/g body weight. Though $\mathrm{LD}_{50}$ of $V$. alginolyticus WW1 is the lowest among the strains, we do not know if it is the most virulent since the tests were conducted in different species. According to Snoussi et al. (2008), V. alginolyticus strains differ in virulence, implying different pathogenic mechanisms. The adaptive responses to different strains may vary in amphioxus. V. alginolyticus WW1, isolated from amphioxus, might provide an option for the study of immunology in amphioxus.

V. alginolyticus WW1 was isolated from cultured amphioxus, indicating that it may be an important pathogen of cultured amphioxus. This study will be helpful to the culture of amphioxus as well as to identify a model pathogen for study of the immune response in amphioxus.

\section{Acknowledgements}

This work was supported by The National Sciences Foundation of China (No. 30972270), the National High-Technology Research and Development Program (863 Program) of China (2008AA092600), and the Scientific and Technological Innovation Project financially supported by Qingdao National Laboratory for Marine Science and Technology (No. 2015ASKJ02).

\section{References}

Ausubel F.M., Brent R., Kingston R.E., Moore D.D., Seidman J.G., Smith J.A. \& Struhl K. 1995. Short Protocols in Molecular Biology. John Wiley \& Sons, New York.

Altschul S.F., Madden T.L., Schaeffer A.A., Zhang J., Zhang Z., Miller W. \& Lipman D.J. 1997. Gapped BLAST and PSIBLAST: a new generation of protein database search programs. Nucleic Acids Res. 25: 3389-3402.

Anguiano-Beltrán C., Lizárraga-Partida M.L. \& Searcy-Bernal R. 2004. Effect of Vibrio alginolyticus on larval survival of the blue mussel Mytilus galloprovincialis. Dis. Aquat. Organ. 59: $119-123$.

Austin B.\& Austin D.A. 1999. Bacterial Fish Pathogens: Disease of Farmed and Wild Fish, $3^{\text {rd }}$ Ed. Springer-Verlag, Berlin.

Balcázar J.L., Gallo-Bueno A., Planas M. \& Pintado J. 2010. Isolation of Vibrio alginolyticus and Vibrio splendidus from captive-bred seahorses with disease symptoms. Antonie Van Leeuwenhoek 97: 207-210.

Balebona M.C., Andreu M.J., Bordas M.A., Zorrilla I., Moriñigo M.A. \& Borrego J.J. 1998. Pathogenicity of Vibrio alginolyticus from cultured gilt-head sea bream (Sparus aurata L.). Appl. Environ. Microbiol. 64: 4269-4275.
Ben Kahla-Nakbi A., Chaieb K. \& Bakhrouf A. 2009. Investigation of several virulence properties among Vibrio alginolyticus strains isolated from diseased cultured fish in Tunisia. Dis. Aquat. Organ. 86: 21-28.

Ben Kahla-Nakbi A., Chaieb K., Besbes A., Zmantar T. \& Bakhrouf A. 2006. Virulence and enterobacterial repetitive intergenic consensus PCR of Vibrio alginolyticus strains isolated from Tunisian cultured gilthead sea bream and sea bass outbreaks. Vet. Microbiol. 117: 321-327.

Brenner D.J., Krieg N.R. \& Staley J.T. 2004a. Bergey's Manual of Systematic Bacteriology, $2^{\text {nd }}$ Ed., Vol. 2, Part B, p. 513.

Brenner D.J., Krieg N.R. \& Staley J.T. 2004b. Bergey's Manual of Systematic Bacteriology, $2^{\text {nd }}$ Ed., Vol. 2, Part B, p. 560.

Cai J., Han H., Song Z., Li C.\& Zhou J. 2006. Isolation and characterization of pathogenic Vibrio alginolyticus from diseased postlarval abalone, Haliotis diversicolor supertexta (Lischke). Aquacult. Res. 37: 1222-1226.

Cannon J.P., Haire R.N. \& Litman G.W. 2002. Identification of diversified genes that contain immunoglobulin-like variable regions in a protochordate. Nat. Immunol. 3: 1200-1207.

Chun J., Lee J.H., Jung Y., Kim M., Kim S., Kim B.K. \& Lim Y.W. 2007. EzTaxon: a web-based tool for the identification of prokaryotes based on $16 \mathrm{~S}$ ribosomal RNA gene sequences. Int. J. Syst. Evol. Microbiol. 57: 2259-2261.

Colwell R.R. \& Grimes D.J. 1984. Vibrio diseases of marine fish populations. Helgol. Mar. Res. 37: 265-287.

Di Pinto A., Ciccarese G., Tantillo G., Catalano D. \& Forte V.T. 2005. A collagenase-targeted multiplex PCR assay for identification of Vibrio alginolyticus, Vibrio cholerae, and Vibrio parahaemolyticus. J. Food Prot. 68: 150-153.

Fang Y.Q. 1987. Ecological habits and protection of amphioxus. Chin. J. Zool. 22: 41-45 (in Chinese).

Felsenstein J. 1985. Confidence limits on phylogenies: an approach using the bootstrap. Evolution 39: 783-791.

Gans C. 1996. Study of lancelets: the first 200 years. Israel J. Zool. 42: S3-S11.

Gomez-Leon J., Villamil L., Lemos M.L., Novoa B. \& Figueras A. 2005. Isolation of Vibrio alginolyticus and Vibrio splendidus from aquacultured carpet shell clam (Ruditapes decussatus) larvae associated with mass mortalities. Appl. Environ. Microbiol. 71: 98-104.

González-Escalona N., Blackstone G.M. \& DePaola A. 2006. Characterization of a Vibrio alginolyticus strain, isolated from Alaskan oysters, carrying a hemolysin gene similar to the thermostable direct hemolysin-related hemolysin gene (trh) of Vibrio parahaemolyticus. Appl. Environ. Microbiol. 72: 7925-7929.

Huang G.H., Liu H., Han Y., Fan L.F., Zhang Q.F., Liu J.Z., Yu X.S., Zhang L.C., Chen S.W., Dong M.L., Wang L. \& Xu A.L. 2007. Profile of acute immune response in Chinese amphioxus uponStaphylococcus aureus and Vibrio parahaemolyticus infection. Dis. Aquat. Organ. 31: 1013-1023.

Holland L.Z. 2014. Genomics, evolution and development of amphioxus and tunicates: the goldilocks principle. J. Exp. Zool. 324B: $342-352$.

Holland L.Z. \& Yu J.K. 2004. Cephalochordate (amphioxus) embryos: procurement, culture, and basic methods. Methods Cell Biol. 74: 195-215.

Holland N.D., Holland L.Z. \& Holland P.W. 2015. Scenarios for the making of vertebrates. Nature 520: 450-455.

Jukes T.H. \& Cantor C.R. 1969. Evolution of protein molecules, pp. 21-132. In: Munro H.N. (ed.) Mammalian Protein Metabolism. Academic Press, New York.

Lane D.J. 1991. 16S/23S rRNA sequencing, pp. 115-175. In: Stackebrandt E. \& Goodfellow M. (eds) Nucleic Acid Techniques in Bacterial Systematics. John Wiley \& Sons, New York.

Lee D.Y., Moon S.Y., Lee S.O., Yang H., Lee H.J. \& Lee M.S. 2008. Septic shock due to Vibrio alginolyticus in a cirrhotic patient: the first case in Korea. Yonsei Medical Journal 49: 329-332.

Lee K.K., Yu S.R., Chen F.R., Yang T.I. \& Liu P.C. 1996a. Virulence of Vibrio alginolyticus isolated from diseased tiger prawn, Penaeus monodon. Curr. Microbiol. 32: 229-231. 
Lee K.K., Yu S.R., Yang T.I., Liu P.C. \& Chen F.R. 1996b. Isolation and characterization of Vibrio alginolyticus isolated from diseased kuruma prawn, Penaeus japonicus. Lett. Appl. Microbiol. 22: 111-114.

Lhafi S.K. \& Kühne M. 2007. Occurrence of Vibrio spp. in blue mussels (Mytilus edulis) from the German Wadden Sea. Int. J. Food Microbiol. 116: 297-300.

Li J. 2002. Vibrio alginolyticus: Pathogenicity and Its Immunological Control via Vaccination in Silver Sea Bream, Sparussarba. Ph.D. Thesis, The Chinese University of Hong Kong, Hong Kong, People's Republic of China, 242 pp.

Liu H., Wang Q.Y., Liu Q., Cao X.D., Shi C.B. \& Zhang Y.X. 2011. Roles of Hfq in the stress adaptation and virulence in fish pathogen Vibrio alginolyticus and its potential application as a target for live attenuated vaccine. Appl. Microbiol. Biotechnol. 91: 353-364.

Liu P.C., Chen Y.C. \& Lee K.K. 2001. Pathogenicity of Vibrio alginolyticus isolated from diseased small abalone Haliotis diversicolor supertexta. Microbios 104: 71-77.

Martins M.L., Mouriño J.L., Fezer G.F., BuglioneNeto C.C., Garcia P., Silva B.C., Jatobá A. \& Vieira F. 2010. Isolation and experimental infection with Vibrio alginolyticus in the sea horse, Hippocampus reidi Ginsburg, 1933 (Osteichthyes: Syngnathidae) in Brazil. Braz. J. Biol. 70: 205-209.

Nei M. \& Kumar S. 2000. Molecular Evolution and Phylogenetics. Oxford University Press, New York.

Pang Q., Zhang S., Liu X. \& Wu D. 2006. Humoral immune responses of amphioxus Branchiostoma belcheri to challenge with Escherichia coli. Fish Shellfish Immunol. 21: 139-145.

Pang Q., Zhang S. \& Zhao B. 2009. Induction of phenoloxidases in the humoral fluids of amphioxus Branchiostoma belcheri by Vibrio alginolyticus and Escherichia coli. Fish Shellfish Immunol. 26: 669-671.

Pang Q., Zhang S. \& Zhao B. 2010. Immune parameters in the humoral fluids of amphioxus Branchiostoma belcheri challenged with Vibrio alginolyticus. Fish Shellfish Immunol. 28: $232-234$.

Reed L.J. \& Muench H. 1938. A simple method of estimating fifty percent endpoints. Am. J. Hyg. 27: 493-497.

Reilly G.D., Reilly C.A., Smith E.G. \& Baker-Austin C. 2011. Vibrio alginolyticus-associated wound infection acquired in British waters, Guernsey, July 2011. Euro Surveill. 16: Pii: 19994.

Saitou N. \& Nei M. 1987. The neighbor-joining method: a new method for reconstructing phylogenetic trees. Mol. Biol. Evol. 4: $406-425$

Sato A., Mayer W.E. \& Klein J. 2003. A molecule bearing an immunoglobulin-like $\mathrm{V}$ region of the CTX subfamily in amphioxus. Immunogenetics 55: 423-427.

Selvin J. \& Lipton A.P. 2003. Vibrio alginolyticus associated with white spot disease of Penaeus monodon. Dis. Aquat. Organ. 57: $147-150$.
Snoussi M., Noumi E., Usai D., Sechi L.A., Zanetti S. \& Bakhrouf A. 2008. Distribution of some virulence related-properties of Vibrio alginolyticus strains isolated from Mediterranean seawater (Bay of Khenis, Tunisia): investigation of eight Vibrio cholerae virulence genes. World J. Microbiol. Biotechnol. 24: 2133-2141.

Tamura K., Stecher G., Peterson D., Filipski A. \& Kumar S. 2013. MEGA6: Molecular Evolutionary Genetics Analysis version 6.0. Mol. Biol. Evol. 30: 2725-2729.

Thompson F.L., Austin B. \& Swings J. 2006. The Biology of Vibrios. ASM Press, Washington.

Thompson F.L., Lida T. \& Swings J .2004. Biodiversity of vibrios. Microbiol. Mol. Biol. Rev. 68: 403-431.

Wang G., Zhang S. \& Wang Z. 2009. Responses of alternative complement expression to challenge with different combinations of Vibrio anguillarum, Escherichia coli and Staphylococcus aureus: evidence for specific immune priming in amphioxus Branchiostoma belcheri. Fish Shellfish Immunol. 26: 33-39.

Wong H.C., Ting S.H. \& Shieh W.R. 1992. Incidence of toxigenic vibrios in foods available in Taiwan. J. Appl. Bacteriol. 73: 197-202.

Wu X., Zhang S., Wang Y., Zhang B., Qu Y. \& Jiang X. 1994. Laboratory observations on spawning, fecundity and larval development of amphioxus (Branchiostoma belcherit singtauense). Chin. J. Oceanol. Limnol. 12: 289-294.

Yasui K., Urata M., Yamaguchi N., Ueda H. \& Henmi Y. 2007. Laboratory culture of the Oriental lancelet Branchiostoma belcheri. Zool. Sci. 24: 514-520.

Yu C., Dong M., Wu X., Li S., Huang S., Su J., Wei J., Shen Y., Mou C., Xie X., Lin J., Yuan S., Yu X., Yu Y., Du J., Zhang S., Peng X., Xiang M. \& Xu A. 2005. Genes "waiting" for recruitment by the adaptive immune system: the insights from amphioxus. J. Immunol. 174: 3493-3500.

Zhang Z., Schwartz S., Wagner L. \& Miller W. 2000. A greedy algorithm for aligning DNA sequences. J. Comput. Biol. 7: 203-214.

Zhou Z.J., Pang H.Y., Ding Y., Cai J., Huang Y.C., Jian J.C. \& Wu Z.H. 2013. VscO, a putative T3SS chaperone escort of Vibrio alginolyticus, contributes to virulence in fish and is a target for vaccine development. Fish Shellfish Immunol. 35: 1523-1531.

Zorrilla I., Moriñigo M.A., Castro D., Balebona M.C. \& Borrego J.J. 2003. Intraspecific characterization of Vibrio alginolyticus isolates recovered from cultured fish in Spain. J. Appl. Microbiol. 95: 1106-1116.

Received December 12, 2015 Accepted June 15, 2016 